\title{
Are Time-Based and Event-Based Prospective Memory Affected by Normal Aging in the Same
} Way?

\author{
C. Bastin and T. Meulemans
}

\section{(2) OpenEdition Journals}

Electronic version

URL: http://journals.openedition.org/cpl/154

DOI: $10.4000 / \mathrm{cpl} .154$

ISSN: $1379-6100$

\section{Publisher}

Centre PsyCLÉ

\section{Printed version}

Date of publication: 1 April 2002

\section{Electronic reference}

C. Bastin and T. Meulemans, « Are Time-Based and Event-Based Prospective Memory Affected by Normal Aging in the Same Way? », Current psychology letters [Online], 2002/1, 7| 2002, Online since 04 September 2003, connection on 08 September 2020. URL : http://journals.openedition.org/cpl/154 ; DOI : https://doi.org/10.4000/cpl.154

This text was automatically generated on 8 September 2020 .

(c) All rights reserved 


\section{Are Time-Based and Event-Based Prospective Memory Affected by Normal Aging in the Same Way?}

C. Bastin and T. Meulemans 